\title{
Evaluation of the genotoxicity of Euterpe oleraceae Mart. (Arecaceae) fruit oil (açaí), in mammalian cells in vivo
}

\author{
E.S. Marques ${ }^{\text {a }}$, J.G. Froder ${ }^{\text {a }}$, J.C.T. Carvalho ${ }^{\text {b }}$, P.C.P. Rosa ${ }^{\text {, }}$, F.F. Perazzo ${ }^{\text {d, E.L. Maistro }}{ }^{\text {a, e, * }}$ \\ ${ }^{a}$ Universidade Estadual Paulista - UNESP - Instituto de Biociências, Programa de Pós-Graduação em Biologia Geral e Aplicada, Botucatu, SP, Brazil \\ b Laboratório de Pesquisa em Fármacos, Centro de Ciências Biológicas e da Saúde, Colegiado de Farmácia, Universidade Federal do Amapá, Macapá, AP, \\ Brazil \\ ${ }^{\mathrm{c}}$ Universidade Estadual de Campinas - UNICAMP, Faculdade de Ciências Médicas, Campinas, SP, Brazil \\ ${ }^{\mathrm{d}}$ Universidade Federal de São Paulo - UNIFESP, Departamento de Ciências Exatas e da Terra, Diadema, SP, Brazil \\ e Universidade Estadual Paulista - UNESP - Faculdade de Filosofia e Ciências, Departamento de Fonoaudiologia, Marília, SP, Brazil
}

\section{A R T I C L E I N F O}

\section{Article history:}

Received 7 December 2015

Received in revised form

19 April 2016

Accepted 22 April 2016

Available online 25 April 2016

\section{Keywords:}

Euterpe oleracea

Arecaceae

Açaí oil

Phytochemical of açai

Comet assay

Micronucleus test

\begin{abstract}
A B S T R A C T
E. oleracea is a tropical plant from the Amazon region, with its fruit used for food, and traditionally, as an antioxidant, anti-inflammatory, hypocholesterolemic, for atherosclerotic disease, and has anticancer properties. The oil of the fruit has antidiarrheic, anti-inflammatory and antinociceptive activities, but without genotoxicity evaluation. Therefore, the aim of this study was to evaluate the genotoxic potential of E. oleracea fruit oil (EOO), in rat cells. Male Wistar rats were treated with EOO by gavage at doses of 30, 100 and $300 \mathrm{mg} / \mathrm{kg}$, for 14 days, within a $24 \mathrm{~h}$ interval. The DNA damage in the leukocytes, liver, bone marrow and testicular cells, was assessed by the comet assay, and the clastogenic/aneugenic effects in the bone marrow cells, by the micronucleus test. Our phytochemicals characterization of the EOO showed the presence of vanillic, palmitic, $\gamma$-linolenic, linoleic, oleic, cinnamic, caffeic, protocatechuic, ferulic, syringic acids, and flavonoids quercetin and kaempferol rutinoside as the main constituents. Both cytogenetic tests performed showed that EOO presented no significant genotoxic effects in the analyzed cells, at the three tested doses. These results indicate that, under our experimental conditions, E. oleracea fruit oil did not reveal genetic toxicity in rat cells.
\end{abstract}

() 2016 Published by Elsevier Ltd.

\section{Introduction}

Plants have for a very long time, formed the basis of sophisticated traditional medicine systems that have been in existence for thousands of years, and continue to provide mankind with new remedies. They have gained a significant increase in popularity, as complementary and alternative medicines for the prevention and treatment of different infectious and non-infectious diseases in human therapy (Kim et al., 2015; Gurib-Fakim, 2006). According to the literature review data, natural products and their derivatives, represent $50 \%-80 \%$ of all the drugs in clinical use in the world (Sen and Samanta, 2015; Petrovska, 2012).

Euterpe oleracea Mart. (Arecaceae family) is a plant whose fruit is commonly known as "açaî". This fruit is used traditionally in the

\footnotetext{
* Corresponding author. Departamento de Fonoaudiologia, Faculdade de Filosofia e Ciências, Universidade Estadual Paulista (UNESP), Av. Hygino Muzzi Filho, 737. Caixa Postal 18. Campus Universitário. CEP, 17525-900, Marilia, SP, Brazil.

E-mail address: edson.maistro@marilia.unesp.br (E.L. Maistro).
}

Brazilian folk medicine to treat anemia, diarrhea, malaria, pain, inflammation, hepatitis, and kidney diseases (Caetano et al., 2014; de Bem et al., 2014; Vásquez et al., 2014; Souza et al., 2011; Leão et al., 2007). Moreover, açaí is considered a dietary food supplement, in appreciation to its high content of natural antioxidant and can be considered as one of the new superfruits (Yamaguchi et al., 2015). Açaí fruits have been used as a functional food due to its nutritional benefits and therapeutic promise and, for this reason, it is being studied currently, by researchers worldwide (Bonomo Lde et al., 2014). Most of the Amazonian population consume açaí juice daily, and this makes it a fruit of great economic importance (Murrieta et al., 1999). A study by Khayat (2005) showed that, the daily intake of açaí fruit acted as a coadjuvant, to reduce the risk of coronary atherosclerotic disease in a population of the State of Pará in Brazil. Extracts from açaí fruit, induced a vasodilator effect in the rat mesenteric vascular bed, and this suggests its possible use in the treatment of cardiovascular diseases (Rocha et al., 2007). With specific regard to the açaí fruit oil, antidiarrheic action was proven (Plotkin and Balick, 1984) and Favacho et al. (2011) reported anti- 
inflammatory and antinociceptive activities.

Considering the fact that genetic toxicity is a crucial endpoint in the safe testing of plants as it addresses potential mutagenicity, which has implications for risks of both genetic disease and cancer; and that to the best of our knowledge, there are no data in the literature about the genetic toxicity of E. oleracea fruit oil, the aim of this present study was to investigate the genotoxic and clastogenic/ aneugenic potential of this oil in different rat cells, using the comet and micronucleus assays, respectively. Concomitantly, the main chemicals present in this oil were determined.

\section{Material and methods}

\subsection{Chemicals}

Doxorubicin (DXR, Oncodox ${ }^{\circledR}$, Meizler) was used as the DNA damage agent in the comet and micronucleus assays, and was prepared by dissolving it in sterile water. The other main chemicals were obtained from the following suppliers: Normal Melting Point (NMP) agarose (Cat. No. 15510-019: Invitrogen) Low Melting Point (LMP) agarose (Cat. No. 15517-014: Invitrogen), sodium salt $\mathrm{N}$ lauroyl sarcosine (L-5125: Sigma) and ethylenediaminetetraacetic acid (EDTA) (Merck). EOO was dissolved in Tween 80.

\subsection{Plant material}

The E. oleracea Mart. (Arecaceae family) fruit oil (EOO) was kindly provided by the company Açaí do Amapá Agro-Industrial Ltda Sambazon, located in the city of Macapá, in Amapá State, Brazil. The extraction method consisted of a standardized method used by the company, which cannot be published, because of patent protection.

\subsection{Phytochemical analysis}

The Açaí fruit oil was dissolved in methanol:water (1:1) with $0.1 \%$ formic acid for reading in a positive mode and in methanol:water solution (1:1) with $0.1 \%$ ammonium hydroxide to read in the negative mode. The solutions were directly infused into ESI in the Mass Spectrometer (MS). The ESI-MS spectra and ESI-MS/MS were acquired using positive ion mode for the acidic solution, and negative ion mode for the alkaline solution.

The chromatographic separation was performed using an Acquity UPLC BEH hybridizes column (Ethylene bridged hybrid) C18 with dimensions of $50 \mathrm{~mm} \times 2.1 \mathrm{~mm}$ and particle size of $1.7 \mu \mathrm{m}$ at room temperature. The mobile phase consisted of methanol:formic acid $0.1 \% 65 / 35 \mathrm{v} / \mathrm{v}$ with flow of $0.7 \mathrm{~mL} \cdot \mathrm{min}^{-1}$ and injection volume of $5 \mu \mathrm{L}$.

The phytochemical analyses were performed, using an Ultra Performance Liquid Chromatography (UPLC) Waters, Acquity model, coupled to a mass spectrometer TQD model, Waters, with ionization electrospray source and mass analyzer type triple quadrupole -TDQ. To perform the sequential mass analysis, argonium was used as collision gas. The Masslynx software was used for data acquisition and processing. Analyses were initially monitored in full-scan mode of mass detector and then the desired signals were selected for collision induced dissociation.

\subsection{Animals and dosing}

Experiments were carried out in 4-5 weeks old male Wistar rats, weighing about $100 \mathrm{~g}-120 \mathrm{~g}$. The animals were acquired from the animal's house of the Universidade Estadual Paulista (UNESP), Botucatu, São Paulo state, Brazil, and kept in polyethylene boxes, in a climate controlled environment $\left(22 \pm 4{ }^{\circ} \mathrm{C}, 55 \pm 5 \%\right.$ of relative humidity) with a 12 h light-dark cycle (7:00 a.m. to 7:00 p.m.). Food (NUVILAB CR1-NUVITAL) and water were available ad libitum. The animals were divided into five experimental groups, with six animals in each group. The EOO (30 mg/kg, $100 \mathrm{mg} / \mathrm{kg}$ or $300 \mathrm{mg} /$ $\mathrm{kg}$ b.w.) was diluted in vehicle ( $1 \%$ Tween 80 ) and administered by gavage daily for 14 consecutive days, at $24 \mathrm{~h}$ interval. In this procedure, each animal was weighed individually and then the calculated dose, was solubilized in $0.4 \mathrm{~mL}$ of the vehicle being administered. These doses were selected based on its traditional use in Brazil (25 ml-30 ml daily) (http://beneficiosnaturais.com.br/ oleo-de-acai-beneficios-e-propriedades/), and also, on our preliminary acute toxicity studies in rats. At the dose of $300 \mathrm{mg} / \mathrm{kg}$, some animals began to display signs of toxicity such as diarrhea and bristling of the hair. For this reason, higher doses were not tested. The negative control group received only vehicle by gavage, and the positive control group received an intraperitoneal injection of doxorubicin (DX R) at $16 \mathrm{mg} / \mathrm{kg}$ body weight. On the 15 th day, $24 \mathrm{~h}$ after the administration of the last treatment, the rats were anesthetized with xylazine and ketamine ( $4 \mathrm{mg} / \mathrm{kg}$ b.w., i.p.), and the peripheral blood from the tail was collected to the comet assay. Immediately after this, the animals were euthanized by cervical dislocation, and the liver, bone marrow and testicle cells were collected for comet assay, and the bone marrow from another femur for micronucleus test. The Animal Bioethics Committee of the Faculdade de Medicina de Marília (CEUA/FAMEMA, Marília, São Paulo state, Brazil) approved this present study on the 31st of January, 2013 (protocol number 1659/12), in accordance with the federal government legislations on animal care.

\subsection{Comet assay}

The comet assay (SCGE) was carried out through the method described by Speit and Hartmann (1999), which was based on the original work of Singh et al. (1988), and includes modifications introduced by Klaude et al. (1996), as well as some additional modifications. Briefly, peripheral blood samples from the vein in the tail, and liver, bone marrow, and testicular cell samples were washed with saline solution, in an ice bath. A small portion (diameter of about $4 \mathrm{~mm}$ ), was transferred to a Petri dish containing $1 \mathrm{ml}$ of Hank's solution ( $\mathrm{pH}$ of 7.5) and then homogenized gently with small pinches and a syringe to avoid clumps of cells. An aliquot of $20 \mu \mathrm{l}$ was removed from the supernatant of each cell type to determine cell viability. Cell counting was performed using a hemocytometer. Cell viability was determined by trypan blue dye exclusion. The number of trypan blue-negative cells was considered as well as the number of viable cells, and it was greater than $85 \%$. Another equal aliquot of cells from each animal was mixed with $120 \mu \mathrm{l}$ of $0.5 \%$ low melting point agarose at $37^{\circ} \mathrm{C}$, and rapidly spread on two microscope slides per animal, precoated with $1.5 \%$ normal melting point agarose. The slides were coverslipped and allowed to gel at $4{ }^{\circ} \mathrm{C}$ for $20 \mathrm{~min}$. The coverslips were gently removed, and the slides were then immersed in cold, freshly prepared lysis solution consisting of $89 \mathrm{ml}$ of a stock solution $(2.5 \mathrm{M}$ $\mathrm{NaCl}, 100 \mathrm{mM}$ EDTA, $10 \mathrm{mM}$ Tris, pH set to 10.0 with $8 \mathrm{~g}$ of solid $\mathrm{NaOH}, 890 \mathrm{ml}$ of distilled water and $1 \%$ sodium lauryl sarcosine), plus $1 \mathrm{ml}$ of Triton X-100 (Merck) and $10 \mathrm{ml}$ of DMSO (Merck). The slides, which were protected from light, were allowed to stand at $4{ }^{\circ} \mathrm{C}$ for $1 \mathrm{~h}$, and then placed in the gel box, positioned at the anode end, and left in a high $\mathrm{pH}(>13)$ electrophoresis buffer $(300 \mathrm{mM}$ $\mathrm{NaOH}-1 \mathrm{mM}$ EDTA, prepared from a stock solution of $10 \mathrm{M} \mathrm{NaOH}$ and $200 \mathrm{mM}, \mathrm{pH} 10.0$, EDTA) at $4{ }^{\circ} \mathrm{C}$ for $20 \mathrm{~min}$, prior to electrophoresis, to allow DNA unwinding. The electrophoresis run was carried out in an ice bath $\left(4^{\circ} \mathrm{C}\right)$ for $20 \mathrm{~min}$ at $300 \mathrm{~mA}$ and $25 \mathrm{~V}$ $\left(0.722 \mathrm{~V} \mathrm{~cm}^{-1}\right)$. The slides were then submerged in a neutralization buffer $(0.4 \mathrm{M}$ Tris $-\mathrm{HCl}, \mathrm{pH} 7.5)$ for $15 \mathrm{~min}$, dried at room 
temperature and fixed in $100 \%$ ethanol for $10 \mathrm{~min}$. The slides were dried and stored overnight or longer, before staining. For the staining process, the slides were briefly rinsed in distilled water, covered with $30 \mu \mathrm{l}$ of $1 \times$ ethidium bromide staining solution prepared from a $10 \times$ stock $(200 \mu \mathrm{g} \mathrm{ml}-1)$ and coverslipped. The material was evaluated immediately at $400 \times$ magnification, using a fluorescence microscope (Olympus BX 50) with a $515 \mathrm{~nm}-560 \mathrm{~nm}$ excitation filter and a $590 \mathrm{~nm}$ barrier filter. Only individual nucleoids were scored. The extent and distribution of DNA damage indicated by the SCGE assay, was evaluated by examining at least 100 randomly selected and non overlapping cells (50 cells per coded slide) per animal in a blind analysis ( six mice per group). These cells were scored visually, according to tail size, into the following four classes: class 0 , no tail; class 1 , tail shorter than the diameter of the head (nucleus); class 2, tail length 1-2 times the diameter of the head; and class 3, tail length more than twice the diameter of the head. Comets with no heads, with nearly all of the DNA in the tail, or with a very wide tail, were excluded from the evaluation because, they probably represented dead cells (Hartmann and Speit, 1997). The total score for 100 comets, which ranged from 0 (all undamaged) to 300 (all maximally damaged), was obtained by multiplying the number of cells in each class by the damage class.

\subsection{Micronucleus test}

The assay was carried out, following standard protocols as recommended by Schmid (1975) and Maistro (2014). The same six male rats from each group used in the comet assay, were used for this assay. The bone marrow from one femur, was flushed out using $2 \mathrm{ml}$ of saline $(0.9 \% \mathrm{NaCl})$ and centrifuged for $7 \mathrm{~min}$. The supernatant was discarded and smears were made on the slides. The slides were coded for a "blind" analysis, fixed with methanol and stained with Giemsa. For the analysis of the micronucleated cells, 2000 Polychromatic Erythrocytes (PCE) per animal were scored, to determine the clastogenic and/or aneugenic property of the EOO. To detect possible cytotoxic effects, the PCE/NCE (Normochromatic Erythrocytes) ratio in 200 erythrocytes/animal was calculated (Gollapudi and McFadden, 1995). The cells were blindly scored using a light microscope at $1000 \times$ magnification. The mean number of Micronucleated Polychromatic Erythrocytes (MNPCE) for each individual rat was used as the experimental unit, with variability (standard deviation) based on differences among animals within the same group.

\subsection{Statistical analysis}

After verifying for normal distribution (normality test KS performed), the data obtained from comet assay, were submitted for Analysis of Variance (ANOVA) and the Tukey-Kramer multiple comparison test (Sokal and Rohlf, 1995), and the data obtained from micronucleus assay, were submitted for the analysis of variance test (ANOVA) with linear regression, both using the GraphPad Prism ${ }^{\circledR}$ software (version 5.02). A value of $P<0.05$ was considered statistically significant for all the parameters evaluated.

\section{Results}

The lipid fraction of açaíberry oil was analyzed using both the negative and positive method. The chemical profile of the polyphenols fatty acids present in the fraction of the dichloromethane and methanol of açaíberry oil extracts, were analyzed using "fingerprint" by negative mode by LC/ESI-MS. The fractions showed peaks at $169.1 \mathrm{~m} / \mathrm{z}[\mathrm{M}-\mathrm{H}] ; 255.3 \mathrm{~m} / \mathrm{z}[\mathrm{M}-\mathrm{H}] ; 277.2 \mathrm{~m} / \mathrm{z}[\mathrm{M}-\mathrm{H}]$, $279.3 \mathrm{~m} / \mathrm{z}[\mathrm{M}-\mathrm{H}]$ and $281.4 \mathrm{~m} / \mathrm{z}[\mathrm{M}-\mathrm{H}]$, corresponding to the deprotonated molecules of the vanillic acid, palmitic acid, $\gamma$-linolenic acid, linoleic acid, and oleic acid, respectively. These peaks can be seen in the chromatogram (Fig. 1). In the positive mode, phenolic acids were identified as cinnamic acid with peak at $149.1 \mathrm{~m} / z$ and caffeic acid with peak at $181.1 \mathrm{~m} / \mathrm{z}$ (Fig. 2). The methanol fraction (considered aqueous) was also analyzed using the negative mode. It was possible to identify the presence of flavonoids: quercetin, deprotonated molecule [M-H] $301.3 \mathrm{~m} / \mathrm{z}$ and kaempferol rutinoside, $[\mathrm{M}-\mathrm{H}] 593.1 \mathrm{~m} / \mathrm{z}$ (Fig. 3). Other compounds were identified as protocatechuic acid [M-H] $155.1 \mathrm{~m} / \mathrm{z}$; ferulic acid [M-H] $195.1 \mathrm{~m} / \mathrm{z}$ and syringic acid [M-H] $199.1 \mathrm{~m} / \mathrm{z}$ (Fig. 4).

Some isolated toxic clinical signs such as diarrhea, were observed in the animals treated with $300 \mathrm{mg} / \mathrm{kg}$ EOO. The cell viability observed in the trypan blue staining protocol was over $85 \%$ in all the treatments (data not shown). DNA damage was evaluated in the blood leukocytes, liver, bone marrow and testicular cells of Wistar rats. The results of the comet assay, are presented in Fig. 5. No significant induction of DNA strand breaks was observed in any of the EOO treated groups. In the few nucleoids that presented DNA damage, it was minor (class 1 ), as was also observed in the vehicle control. Positive control DXR, induced a significant increase in DNA damage $(\mathrm{p}<0.001)$ as shown by the scores obtained for all the cell types analyzed, validating the species selected and the study design used to detect genotoxic effects.

Clastogenic/aneugenic damage was investigated, by analyzing micronuclei formation in the bone marrow Polychromatic Erythrocytes (PCE). Exposure to EOO, did not induce any significant increase in the micronucleus frequency in the bone marrow cells, as well as no significant difference/increase in the PCE/NCE ratio $(P<0.05)$ (Table 1$)$. As expected, exposure to induced positive control DXR led to a significant increase in the number of micronucleated cells when compared to the vehicle control $(P<0.001)$. Cytotoxicity in the bone marrow cells, was measured by quantifying the PCE/NCE ratio and it revealed that EOO did not decrease the PCE/NCE ratio compared to the control.

\section{Discussion}

Natural products can be considered as compounds derived from biological sources like plants, minerals and organic matter and, it is important that they possess biological properties, and are also used for therapeutic medicine on man and animals (Sharma and Gupta, 2015; Grover et al., 2002). To discover how drugs are developed from natural sources, it has become necessary to conduct a study, combining the botanical, phytochemical, biological, and molecular techniques (Sen and Samanta, 2015). Some of these techniques include, the UPLC (phytochemical analysis), comet assay and micronucleus test (evaluation of genotoxic/mutagenic potential), where the identification of the biomolecules and biological activities of these compounds need to be investigated (Hobbs et al., 2015; Trentin Dda et al., 2011; Saleem et al., 2009; Tice et al., 2000).

Chemical studies on açaí have shown that this fruit contains polyphenolic components with antioxidant properties, especially the presence of bioactive substances, such as phenolics, flavonoids and anthocyanins (Pozo-Insfran et al., 2004). Favacho et al. (2011) observed the presence of the fatty acids, oleic, palmitic and palmitoleic as the major compounds of the açaí fruit oil. In the present study, the UPLC analysis of the EOO confirmed the compounds described by Favacho et al. (2011), and also revealed vanillic acid, palmitic acid, $\gamma$-linolenic acid, linoleic acid, oleic acid, cinnamic acid, caffeic acid, protocatechuic acid, ferulic acid, syringic acid, flavonoids quercetin and kaempferol rutinoside as the main constituents. Pacheco-Palencia et al. (2008) evaluating the absorption of the açaí oil using a Caco-2 intestinal cell monolayer demonstrated that phenolic acids such as p-hydroxybenzoic, vanillic, 
acallipo $24,0.337) \mathrm{Sm}(5 G, 5 \times 0.50) \times \mathrm{Sm}(5 G, 5 \times 0.50), \mathrm{Sm}(96,3 \times 1.00) ; \mathrm{Cm}(15.45)$

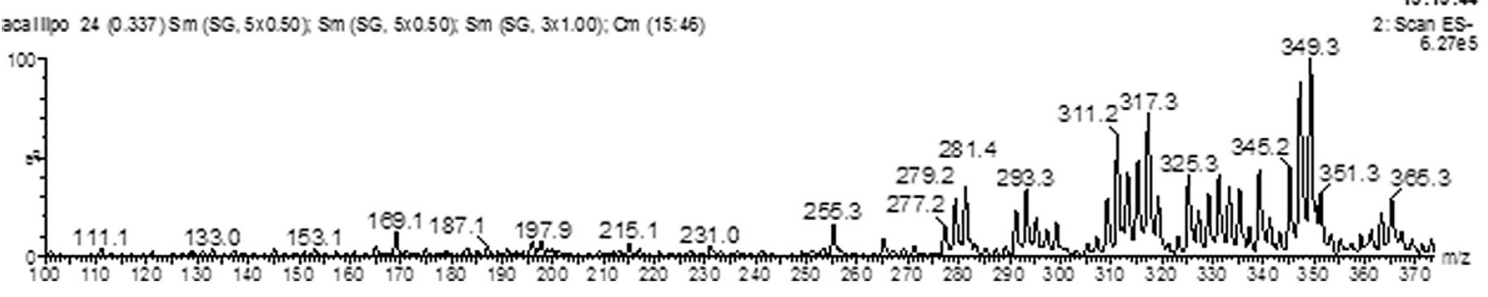

Fig. 1. Analysis of the dichloromethane fraction of the açaíberry oil by LC/ESI-MS (negative mode).

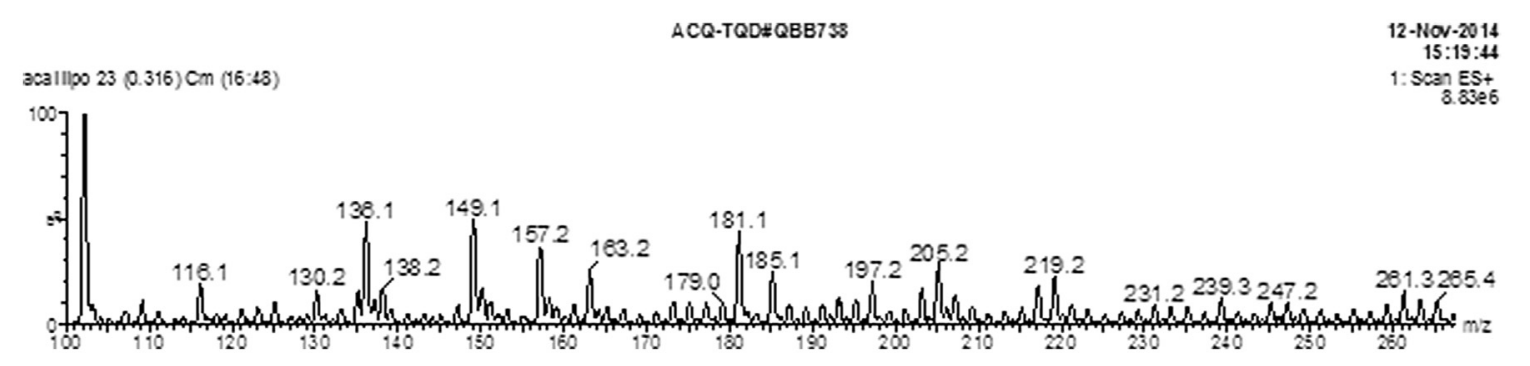

Fig. 2. Analysis of the dichloromethane fraction of the açaiberry oil by LC/ESI-MS (positive mode).

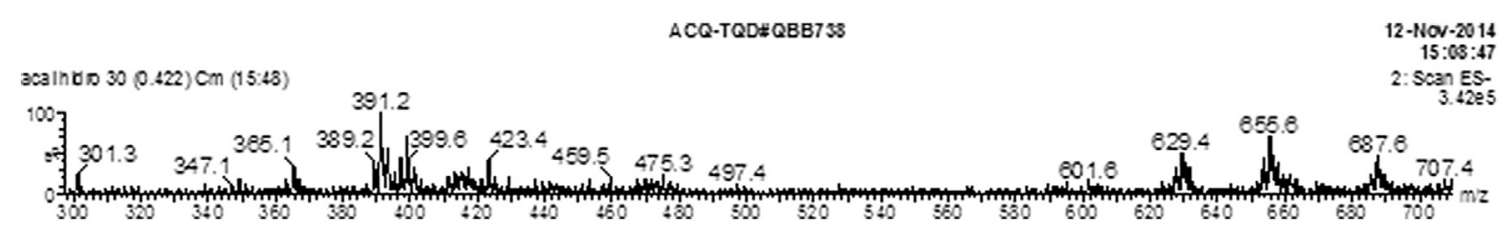

Fig. 3. Analyze of the methanolic fraction of the açaiberry oil by LC/ESI-MS (negative mode).

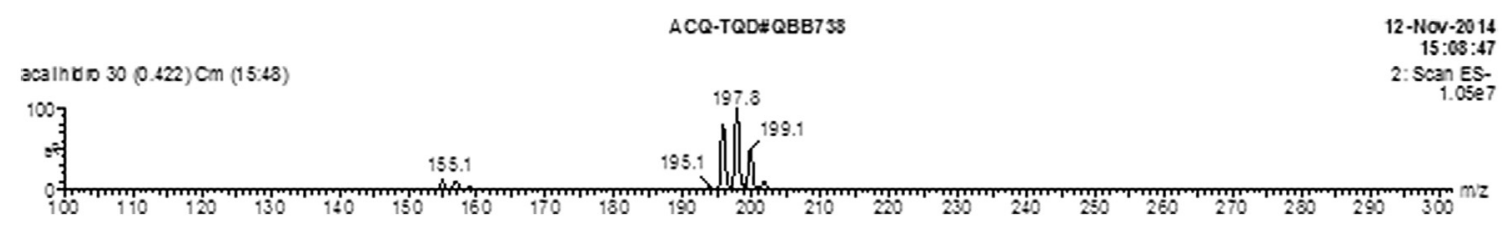

Fig. 4. Analysis of the methanol fraction of the açaiberry oil by LC/ESI-MS (negative mode), focusing on the peaks between 100 and $300 \mathrm{~m} / z$.

syringic, and ferulic acids, in the presence of DMSO, were readily transported from the apical to the basolateral side along with monomeric flavanols such as (+)-catechin and (-)-epicatechin. According to the authors, these results provide evidence for the bioactive properties of açaí polyphenolics in mammal cells.

The genotoxic property of EOO was evaluated using the comet assay. The alkaline version of the comet assay, can measure low levels of DNA damage, such as single and double strand breaks, alkali-labile sites, DNA-DNA and DNA-protein crosslinks (Tice et al., 2000). Our results on the genotoxic evaluation of EOO in vivo in peripheral blood leukocytes, liver, bone marrow and testicular cells indicated that the oil did not present any significant genotoxic effects, under the applied conditions. Is important to remember that, how the cells analyzed in the comet assay were collected $24 \mathrm{~h}$ after the last treatment with the test oil, DNA damage repair processes may have occurred. However, we consider it unlikely, since our pilot in vitro studies, with 4 h exposure of human cells to the EOO, also revealed absence of genotoxicity (unpublished data). Our in vivo results are in agreement with the study of açaí pulp, where Ribeiro et al. (2010), despite some differences in the chemical composition of their study material, also reported the absence of the genotoxic effects of the açaí pulp in peripheral blood leukocytes by the alkaline version of the comet assay.

The second cytogenetic assay performed in the present study to verify the genotoxic potential of EOO, was the micronucleus test. The in vivo assay, is the primary test in a battery of genotoxicity tests recommended by regulatory agencies around the world (Krishna and Hayashi, 2000; Maistro, 2014). The assay measured the clastogenicity (chromosome breakage) and aneugenicity (chromosome lagging due to dysfunction of mitotic apparatus), and estimates the ratio of Polychromatic Erythrocytes (PCE) to Normochromatic Erythrocytes (NCE) which is useful in evaluating any perturbations in hematopoiesis as a result of animal treatment (Krishna and Hayashi, 2000; Gollapudi and McFadden, 1995). The increased $\mathrm{MN}$ frequency may play an important role in the neoplastic development of certain tumors (Murgia et al., 2008). Our results of micronucleus assay, did not show a significant genotoxic effect on the bone marrow cells of the rats, treated with EOO for fourteen consecutive days. The rat historical vehicle control for a period of 10 years in our laboratory show that MNPCE range was $0-8$, with a mean of 2.26 per 2000 PCE; and a positive control had a mean of 13.04 per 2000 PCE. Comparing the responses in treated 
Leukocytes

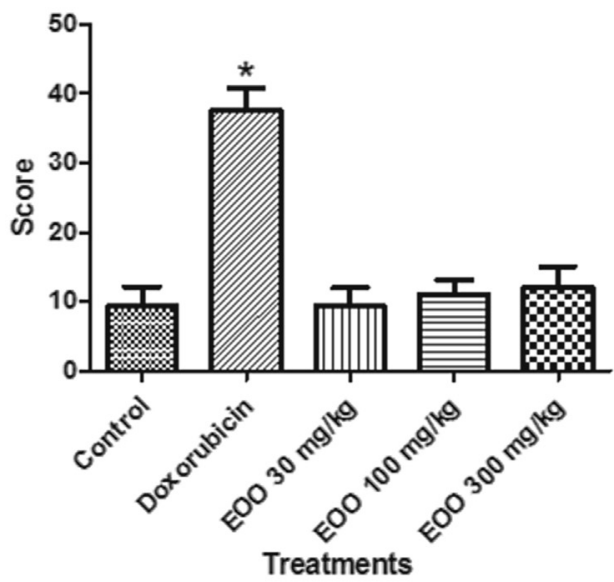

Bone marrow cells

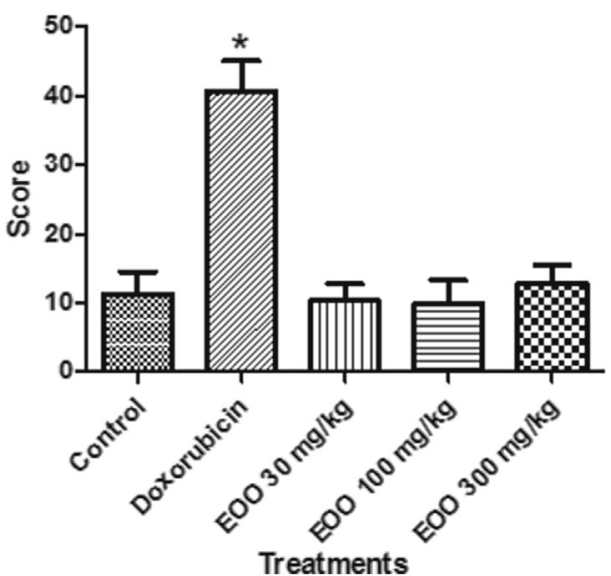

Liver cells

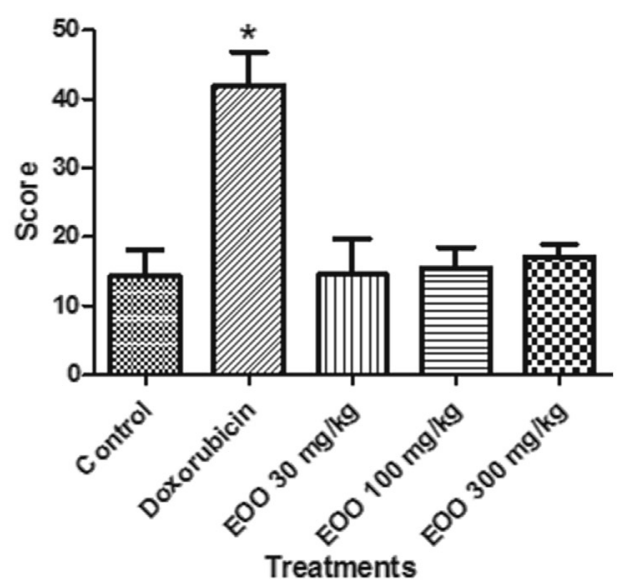

Testicular cells

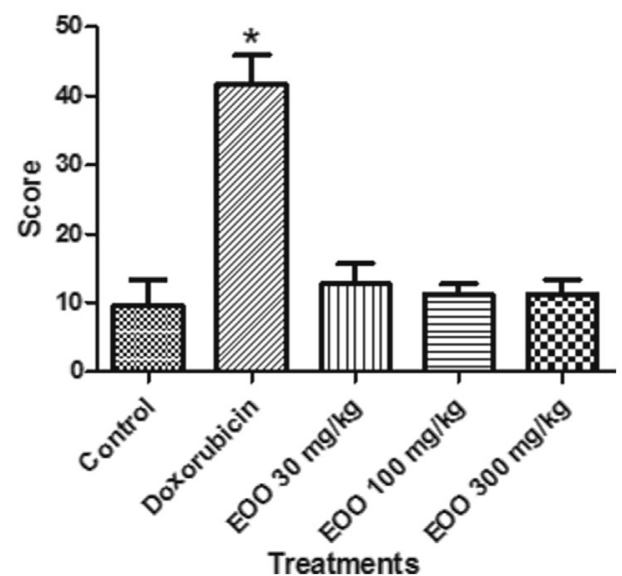

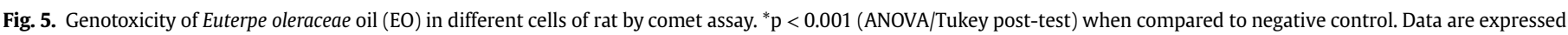
as the mean values obtained from six animals per group $(n=6)$; Score = DNA damage index.

Table 1

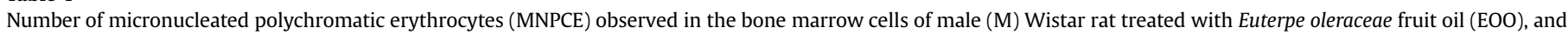
respective control.

\begin{tabular}{|c|c|c|c|c|c|c|c|c|}
\hline \multirow[t]{2}{*}{ Treatments } & \multicolumn{6}{|c|}{ Number of MNPCE per animal } & \multirow[t]{2}{*}{ MNPCE Mean \pm SD } & \multirow[t]{2}{*}{$\mathrm{PCE} / \mathrm{NCE}$ Mean $\pm \mathrm{SD}$} \\
\hline & $\mathrm{M}_{1}$ & $\mathrm{M}_{2}$ & $\mathrm{M}_{3}$ & $\mathrm{M}_{4}$ & $\mathrm{M}_{5}$ & $\mathrm{M}_{6}$ & & \\
\hline $\begin{array}{l}\text { Control } \\
\text { (1\% Tween } 80)\end{array}$ & 2 & 2 & 2 & 2 & 3 & 1 & $2.00 \pm 0.63$ & $1.20 \pm 0.07$ \\
\hline $\begin{array}{l}\text { EOO } \\
(30 \mathrm{mg} / \mathrm{kg})\end{array}$ & 1 & 1 & 3 & 5 & 3 & 2 & $2.50 \pm 1.51$ & $1.19 \pm 0.06$ \\
\hline $\begin{array}{l}\text { EOO } \\
(100 \mathrm{mg} / \mathrm{kg})\end{array}$ & 1 & 3 & 2 & 3 & 2 & 2 & $2.16 \pm 0.75$ & $1.27 \pm 0.11$ \\
\hline $\begin{array}{l}\text { EOO } \\
(300 \mathrm{mg} / \mathrm{kg})\end{array}$ & 2 & 3 & 2 & 2 & 2 & 3 & $2.33 \pm 0.51$ & $1.21 \pm 0.11$ \\
\hline $\begin{array}{l}\text { Doxorubicin } \\
(16 \mathrm{mg} / \mathrm{kg})\end{array}$ & 9 & 9 & 10 & 6 & 7 & 10 & $8.50 \pm 1.64^{*}$ & $1.16 \pm 0.05$ \\
\hline
\end{tabular}

*Significantly different from negative control $(\mathrm{p}<0.001)$.

Two thousand cells per animal were analyzed. SD = standard deviation of the mean.

animals of this present study with the historical controls of our lab, the data obtained also point to absence of clastogenic/aneugenic effects of EOO. Considering this endpoint, our findings are also in accordance with the data obtained from açaí pulp, when the authors observed in both acute and sub-acute treatments, the absence of chromosomal mutations in mice (Ribeiro et al., 2010). Yet, in the study mentioned above, the authors reported an interesting chemoprotective effect of açaí pulp against doxorubicin-induced DNA damage, in different cells of mice, and the protective effects observed can be explained as a result of the antioxidant compounds present in the açaí fruit, which do not present genotoxic effects, as observed in our present study, but present antigenotoxic potential. 
Some of the main components found in the EOO had its genotoxic potential evaluated. Quercetin have contrastant results reported. In some cultured bacterial, human, and rodent cells genotoxic effects were observed (Resende et al., 2012; Barjesteh van Waalwijk van Doorn-Khosrovani et al., 2007; Carver et al., 1983). Some in vivo studies showed an indication for higher incidence of tumors after quercetin exposure (Pamukcu et al., 1980; National Toxicology, 1992) and other revealed negative for genotoxicity in transcriptome analyses of liver and small intestine of mice (Hoek-van den Hil et al., 2015). Kaempferol induced gene and chromosomal mutation in rodent cells in vitro (Maruta et al., 1979; Carver et al., 1983). In vitro genotoxicity assessment of caffeic, cinnamic and ferulic acids on rodent HTC cells showed that the three phenolic acids were not genotoxic by the comet assay but showed clastogenic effects by the micronucleus test (Maistro et al., 2011). Despite of some isolated compounds of EOO to present mutagenic effects, our results showed that the mixture of then in EOO showed no genotoxic effects in different cells of rats.

In conclusion, under the experimental conditions employed in the present work, our findings provide the first evidence that the $E$. oleracea fruit oil, administered by gavage, is not genotoxic in the leukocytes, liver, bone marrow and testicular cells of rats, and by the micronucleus test, that it has no clastogenic/aneugenic effect on the bone marrow either. However, considering that the açaí oil preparation method could not be revealed due to its patent protection, we think that further studies evaluating the E. oleracea fruit oil obtained by other ways and sources are required to better attest its safe use by humans.

\section{Conflict of interest}

The authors declare that they have no conflicts of interest.

\section{Acknowledgments}

The Research was supported by the FAPESP-Fundação de Amparo à Pesquisa do Estado de São Paulo (Grant 2012/17241-8), Brazil. E.S. Marques thanks CAPES for the PhD's degree scholarship and special thanks to Larissa Zochio de Souza for her technical assistance.

\section{Transparency document}

Transparency document related to this article can be found online at http://dx.doi.org/10.1016/j.fct.2016.04.018.

\section{References}

Bonomo Lde, F., Silva, D.N., Boasquivis, P.F., Paiva, F.A., Guerra, J.F., Martins, T.A., de Jesus Torres, A.G., de Paula, I.T., Caneschi, W.L., Jacolot, P., Grossin, N., Tessier, F.J. Boulanger, E., Silva, M.E., Pedrosa, M.L., Oliveira Rde, P., 2014. Açaí (Euterpe oleracea Mart.) modulates oxidative stress resistance in Caenorhabditis elegans by direct and indirect mechanisms. PloS One 9, e89933.

Barjesteh van Waalwijk van Doorn-Khosrovani, S., Janssen, J., Maas, L.M., Godschalk, R.W., Nijhuis, J.G., van Schooten, F.J., 2007. Dietary flavonoids induce MLL translocations in primary human CD34 + cells. Carcinogenesis 28, 1703-1709.

Caetano, R.S., de Souza, A.C.R., Feitozao, L.F., 2014. O uso de plantas medicinais utilizadas por frequentadores dos ambulatórios Santa Marcelina, Porto Velho RO. Rev. Saúde Pesq. 7, 55-63.

Carver, J.H., Carrano, A.V., MacGregor, J.T., 1983. Genetic effects of the flavonoids quercetin, kaempferol, and galangin on Chinese hamster ovary cells in vitro. Mutat. Res. 113, 45-60.

de Bem, G.F., da Costa, C.A., de Oliveira, P.R., Cordeiro, V.S., Santos, I.B., de Carvalho, L.C., Souza, M.A., Ognibene, D.T., Daleprane, J.B., Sousa, P.J., Resende, A.C., de Moura, R.S., 2014. Protective effect of Euterpe oleracea Mart. (açaí) extract on programmed changes in the adult rat offspring caused by maternal protein restriction during pregnancy. J. Pharm. Pharmacol. 66, 1328-1338.

Favacho, H.A.S., Oliveira, B.R., Santos, K.C., Medeiros, B.J.L., Sousa, P.J.C., Perazzo, F.F.,
Carvalho, J.C.T., 2011. Anti-inflammatory and antinociceptive activities of Euterpe oleracea oil. Braz. J. Pharmacogn. 21, 105-114.

Gollapudi, B.B., McFadden, L.G., 1995. Sample size for the estimation of polychromatic to normochromatic erythrocyte ratio in the bone marrow micronucleus test. Mutat. Res. 347, 97-99.

Grover, J.K., Yadav, S., Vats, V., 2002. Medicinal plants of India with anti-diabetic potential. J. Ethnopharmacol. 81, 81-100.

Gurib-Fakim, A., 2006. Medicinal plants: traditions of yesterday and drugs of tomorrow. Mol. Asp. Med. 27, 1-93.

Hartmann, A., Speit, G., 1997. The contribution of cytotoxicity to DNA-effects in the single cell gel test (comet assay). Toxicol. Lett. 90, 183-188.

Hobbs, C.A., Swartz, C., Maronpot, R., Davis, J., Recio, L., Koyanagi, M., Hayashi, S.M., 2015. Genotoxicity evaluation of the flavonoid, myricitrin, and its aglycone, myricetin. Food Chem. Toxicol. 83, 283-292.

Hoek-van den Hil, E.F., van Schothorst, E.M., van der Stelt, I., Hollman, P.C.H. Keijer, J., Rietjens, I.M.C.M., 2015. Quercetin tests negative for genotoxicity in transcriptome analyses of liver and small intestine of mice. Food Chem. Toxicol. 81, 34-39.

Khayat, T.C., 2005. Comportamento do risco para doença aterosclerótica coronária na população de Inhangapí cuja base alimentar é o fruto do açaí (Euterpe oleracea). Trabalho de conclusão de curso. (Graduação em Medicina) - Universidade Federal do Pará. Conselho Nacional de Desenvolvimento Científico e Tecnológico (CNPq), Brazil.

Kim, S.B., Cho, H.J., Kim, Y.S., Kim, D.D., Yoon, I.S., 2015. Modulation of cytochrome P450 activity by 18beta-Glycyrrhetic acid and its consequence on Buspirone pharmacokinetics in rats. Phytother. Res. 29, 1188-1194.

Klaude, M., Eriksson, S., Nygren, J., Ahnstrom, G., 1996. The comet assay: mechanisms and technical considerations. Mutat. Res. 363, 89-96.

Krishna, G., Hayashi, M., 2000. In vivo rodent micronucleus assay: protocol, conduct and data interpretation. Mutat. Res. 455, 155-166.

Leão, R.B.A., Ferreira, M.R.C., Jardim, M.A.G., 2007. Study of therapeutical use plants in municipality of Santa Bárbara do Pará, State of Pará. Braz. Rev. Bras. Farm. 88 (1), 21-25.

Maistro, E.L., 2014. The in vivo rodent micronucleus test. In: Sierra, L.M., Gaivão, I. (Eds.), Genotoxicity and DNA Repair: a Practical Approach, Methods in Pharmacology and Toxicology. Springer Science+Business Media, New York, pp. 103-113.

Maistro, E.L., Angeli, J.P.F., Andrade, S.F., Mantovani, M.S., 2011. In vitro genotoxic assessment of caffeic, cinnamic and ferulic acids. Genet. Mol. Res. 10 $1130-1140$.

Maruta, A., Enaka, K., Umeda, M., 1979. Mutagenicity of quercetin and Kaempferol on cultured mammalian cells. Gann 70, 273-276.

Murgia, E., Ballardin, M., Bonassi, S., Rossi, A.M., Barale, R., 2008. Validation of micronuclei frequency in peripheral blood lymphocytes as early cancer risk biomarker in a nested case-control study. Mutat. Res. 639, 27-34.

Murrieta, R.S.S., Dufour, D., Siqueira, A.D., 1999. Food consumption and subsistence in three caboclo populations on Marajó Island, Amazônia, Brazil. Hum. Ecol. 27, 455-475.

National Toxicology, P, 1992. Toxicology and carcinogenesis studies of quercetin (CAS No. 117-39-5) in F344 rats (feed studies). Natl. Toxicol. Program. Tech. Rep. Ser. 409, 1-171.

Pacheco-Palencia, L.A., Talcott, S.T., Safe, S., Mertens-Talcott, S., 2008. Absorption and Biological activity of phytochemical-rich extracts from açaí (Euterpe oleracea Mart.) pulp and oil in vitro. J. Agr. Food Chem. 56, 3593-3600.

Pamukcu, A.M., Yalciner, S., Hatcher, J.F., Bryan, G.T., 1980. Quercetin, a rat intestinal and bladder carcinogen present in bracken fern (Pteridium aquilinum). Cancer Res. 40, 3468-3472.

Pozo-Insfran, D., Brenes, D., Talcott, S.T., 2004. Phytochemical composition and pigment stability of Açaí (Euterpe oleracea Mart.). J. Agr. Food Chem. 52, $1539-1545$.

Plotkin, M.J., Balick, M., 1984. Medicinal uses of South American palms. J. Ethnopharmacol. 10, 157-179.

Petrovska, B.B., 2012. Historical review of medicinal plants' usage. Pharmacogn. Rev. $6,1-5$.

Resende, F.A., Vilegas, W., Dos Santos, L.C., Varanda, E.A., 2012. Mutagenicity of flavonoids assayed by bacterial reverse mutation (Ames) test. Molecules 17, 5255-5268.

Ribeiro, J.C., Antunes, L.M.G., Aissa, A.F., Darin, J.D.C., De-Rosso, V.V , Mercadante, A.Z. Bianchi, M.L.P. 2010. Evaluation of the genotoxic and antigenotoxic effects after acute and subacute treatments with açaí pulp (Euterpe oleracea Mart.) on mice using erythrocytes micronucleus test and comet assay. Mutat. Res. 695, 22-28.

Rocha, A.P., Carvalho, L.C., Sousa, M.A., Madeira, S.V., Sousa, P.J., Tano, T., SchiniKerth, V.B., Resende, A.C., Moura, R.S., 2007. Endothelium-dependent vasodilator effect of Euterpe oleracea Mart. (Açaí) extracts in mesenteric vascular bed of the rat. Vasc. Pharmacol. 46, 97-104.

Saleem, A., Walshe-Roussel, B., Harris, C., Asim, M., Tamayo, C., Sit, S., Arnason, J.T., 2009. Characterisation of phenolics in Flor-Essence-a compound herbal product and its contributing herbs. Phytochem. Anal. 20, 395-401.

Schmid, W., 1975. The micronucleus test. Mutat. Res. 31, 9-15.

Sen, T., Samanta, S.K., 2015. Medicinal plants, human health and biodiversity: a broad review. Adv. Biochem. Eng. Biotechnol. 147, 59-110.

Sharma, S.B., Gupta, R., 2015. Drug development from natural resource: a systematic approach. Mini Rev. Med. Chem. 15, 52-57.

Singh, N.P., McCoy, M.T., Tice, R.R., Schneider, E.L., 1988. A simple technique for 
quantitation of low levels of DNA damage in individual cells. Exp. Cell Res. 175, 184-191.

Sokal, R.R., Rohlf, F.J., 1995. Biometry: the Principles and Pratice of Statistics in Biological Research, third ed. W.H. Freeman and Company, New York, pp. 175-205. 404-486.

Souza, M.O., Santos, R.C., Silva, M.E., Pedrosa, M.L., 2011. Açaí (Euterpe oleraceae Martius): chemical composition and bioactivity. J. Braz. Soc. Food Nutr. 36, $161-169$.

Speit, G., Hartmann, A., 1999. The comet assay (Single-Cell gel test). In: Henderson, D.S. (Ed.), Methods in Molecular Biology, DNA Repair Protocols: Eukaryotic Systems. Humana Press Inc., Totowa, pp. 203-212.

Tice, R.R., Agurell, E., Anderson, D., Burlinson, B., Hartmann, A., Kobayashi, H. Miyamae, Y., Rojas, E., Ryu, J.C., Sasaki, Y.F., 2000. Single cell gel/comet assay: guidelines for in vitro and in vivo genetic toxicology testing. Environ. Mol. Mutagen 35, 206-221.

Trentin Dda, S., Giordani, R.B., Zimmer, K.R., da Silva, A.G., da Silva, M.V. Correia, M.T., Baumvol, I.J., Macedo, A.J., 2011. Potential of medicinal plants from the Brazilian semi-arid region (Caatinga) against Staphylococcus epidermidis planktonic and biofilm lifestyles. J. Ethnopharmacol. 137, 327-335.

Vásquez, S.P.F., de Mendonça, M.S., Noda, S.N., 2014. Ethnobotany of medicinal plants in riverine communities of the municipality of Manacapuru, Amazonas, Brasil. Acta Amaz. 44 (4), 457-472. http://dx.doi.org/10.1590/18094392201400423.

Yamaguchi, K.K., Pereira, L.F., Lamarao, C.V., Lima, E.S., da Veiga-Junior, V.F., 2015. Amazon acai: chemistry and biological activities: a review. Food Chem. 179, $137-151$. 